\title{
MAJKA BOŽJA SNJEŽNA U PUČKOJ POBOŽNOSTI NA PODRUČJU KRIVOGA PUTA
}

\author{
Marija KULIŠIĆ \\ Sveučilište u Dubrovniku \\ Odjel za umjetnost i restauraciju \\ Ćira Carića 4, 20000 Dubrovnik \\ Ivana VUKOVIĆ \\ Vinkovačka 23 \\ 23000 Split
}

\section{UVOD}

P rilog se temelji na podacima dobivenim tijekom dvokratnog istraživanja pojedinih izričaja pučke pobožnosti u selima i zaselcima na području Krivoga Puta. ${ }^{1}$ Pučka je pobožnost izražavanje kršćanskoga vjerničkog odnosa prema Bogu koje se očituje u izvaliturgijskim i u neliturgijskim oblicima kršćanskoga bogoštovlja (Hoško 2001:383). ${ }^{2}$ Definicija potječe iz crkvenih krugova i uporabiva je u okviru šire shvaćenih teoloških znanosti. Ipak, etnolog ne može polaziti s aksioma kršćanske (rimokatoličke) teologije jer postoji, primjerice, i muslimanska pučka pobožnost koja ne „izražava kršćanski vjernički odnos“ (ibid). Oblici pučke pobožnosti raznovrsni su: razni postovi, hodočašće, klečanje, ophođenje, procesije, dodirivanje svetih likova ili predmeta, paljenje svijeća, moljenje krunice, bratovštine, zavjeti i zavjetni darovi i dr. (Christian 1989:120; Hoško 2001:383; Jukić 1988:81).

Istraživanje izričaja pučke pobožnosti na području Krivoga Puta provedeno je u dva navrata ${ }^{3}$. U svibnju 2004. godine istraživana su vjerovanja u svece zaštitnike tehnikom polustrukturiranog intervjua. Kazivači su govorili o njihovu osobnom štovanju svetaca zaštitnika, pri čemu dominantnu ulogu ima lokalna zaštitnica Majka Božja Snježna. ${ }^{4}$ Njoj u čast je 1856. godine u Podbilu podignuta crkva, a njezin se blagdan slavi 5. kolovoza. Osim glavnog oltara njoj posvećenog (sl. 1), u crkvi se nalazi i kip Majke Božje Snježne (sl. 6, 6a). Iz prvoga dijela istraživanja nastao je poticaj, kao i potreba, za daljnjim bavljenjem vjerovanja u Majku Božju Snježnu kao specifičnim dijelom pučke pobožnosti na području Krivoga Puta. Iste nam se godine pružila mogućnost da prisustvujemo i proslavi njezina blagdana u ulozi sudjelujućih promatrača. ${ }^{5}$ Stoga je ovaj rad rezultat dvovrsnog pristupa istraživanju: s jedne strane koriste se podaci dobiveni putem kazivanja o Majci Božjoj Snježnoj, a s druge podaci koji su rezultat našeg prisustvovanja blagdanu Majke Božje Snježne 2004. godine. Sukladno tome, dobivene podatke prikazat ćemo u dvije

Rad je pod istim naslovom, ali u donekle izmijenjenom obliku, objavljen u Senjskom zborniku 31, 2004. godine, str. 239-260, pod mentorstvom doc. dr. sc. Marijane Belaj s Odsjeka za etnologiju i kulturnu antropologiju Filozofskog fakulteta Sveučilišta u Zagrebu.

2 No, obzirom na to da smo radili na području katoličke vjeroispovijesti, preuzeli smo tu definiciju kao uporabljivu.

3 Voditeljica Projekta Identitet i etnogeneza primorskih Bunjevaca bila je dr. sc. Milana Černelić (Odsjek za etnologiju kulturnu i antropologiju Filozofskog fakulteta Sveučilišta u Zagrebu).

4 Svi podaci kojima se služimo u ovome radu, a koji se odnose na istraživanje u svibnju 2004. godine, nalaze se u transkriptu razgovora koje su s kazivačima vodile dr. sc. Marijana Belaj i Ivana Vuković. Transkript je pohranjen pri Odsjeku za etnologiju i kulturnu antropologiju Filozofskog fakulteta Sveučilišta u Zagrebu.

5 Podaci prikupljeni u kolovozu 2004. godine nalaze se u sintezi našega istraživanja, transkriptu razgovora s kazivačima i na videozapisu koji su pohranjeni pri Odsjeku za etnologiju i kulturnu antropologiju Filozofskog fakulteta Sveučilišta u Zagrebu. 


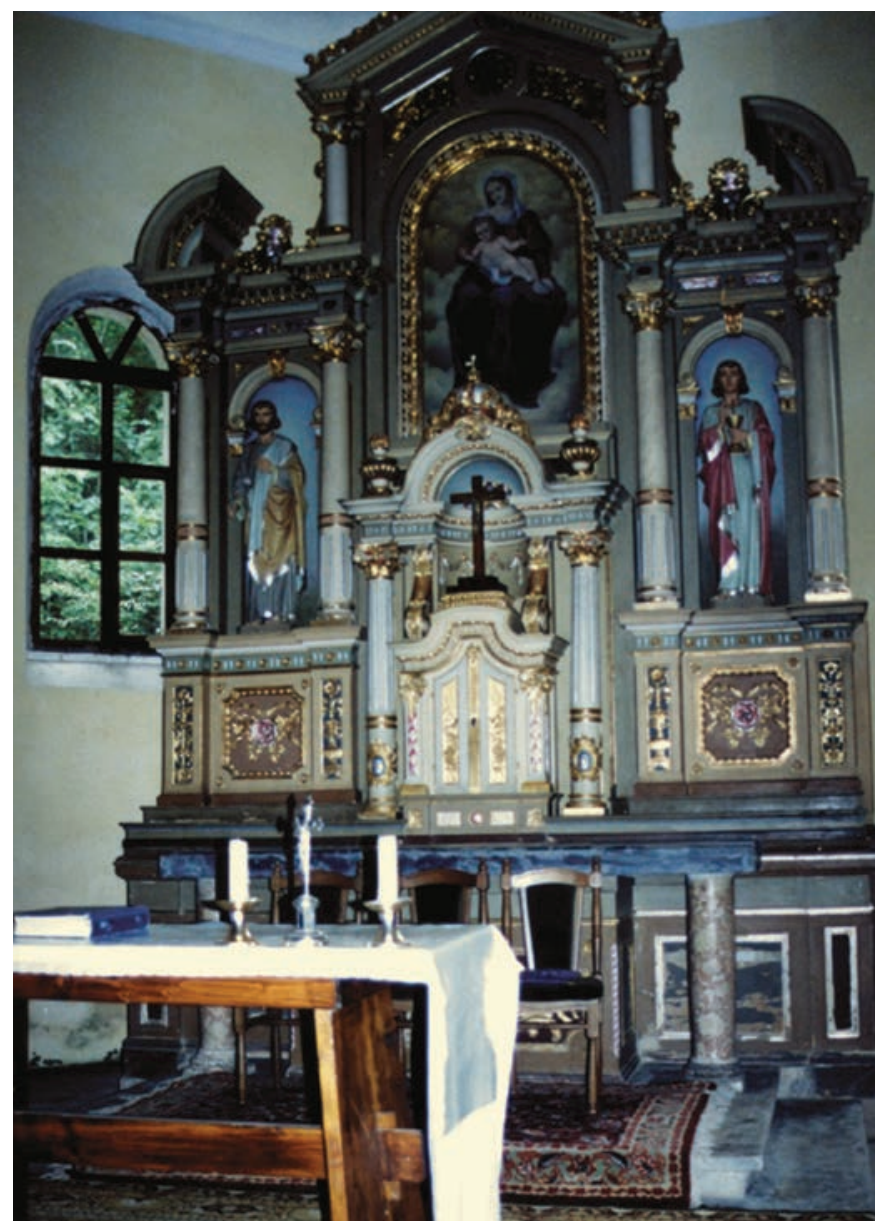

Slika 1: Oltar posvecén Majci Božjoj Snježnoj, Podbilo; snimila Marija Kulišić 5. kolovoza 2004. cjeline. Gdje je moguće, rezultate oba dijela istraživanja komparirat ćemo, prikazati cjelovito, a u drugom ćemo dijelu detaljno opisati sam događaj proslave blagdana. Iako nije moguće u potpunosti komparirati podatke, ta su dva pristupa istraživanju teme pridonijela boljem uvidu u fenomen vjerovanja u Majku Božje Snježnu i njegovu dubljem razumijevanju.

Na samome početku željele bismo ukazati i na neke poteškoće koje su se pojavile u oblikovanju rada. Vjerovanje je samo po sebi složen fenomen, poglavito jer se temelji na osobnom iskustvu. Ono uključuje materijalno i nematerijalno, odnosno vidljivo i nevidljivo. Osobno je iskustvo uvijek različito od drugoga osobnog iskustva, pa je teško komparirati i sintetizirati takvu vrstu podataka. Vidljivi, manifestacijski elementi pogodniji su za takav pristup, no ne omogućuju cjelovitije razumijevanje fenomena vjerovanja. Ono što nedostaje za dublje shvaćanje jest ono nemanifestacijsko, unutarnje $\mathrm{i}$ individualno, vjerovanje i vrednovanje vjerskih praksi ${ }^{6}$.

Podaci dobiveni iz kazivanja uglavnom se odnose na prošlost. Uz njih su izneseni i podaci dobiveni našim sudjelovanjem na proslavi blagdana Majke Božje Snježne, 5. kolovoza 2004. godine u Podbilu, a koji se odnose na sadašnjost. Za pojedine izričaje pobožnosti nije navedeno vrijeme na koje se odnose jer takvo određenje katkad prilikom istraživanja nije bilo moguće. Primjerice, zavjeti kao izrazi pobožnosti mogu trajati vrlo dugo, a neki traju nepromijenjeni godinama, do danas.

U razgovoru s kazivačima pokazalo se da je proslava blagdana Majke Božje Snježne doživjela promjene sukladne promjenama političkog okruženja. Miroslava Filipaš iz Podbila tako kazuje: Uvijek su vjerovali, samo se jedno vrijeme nije moglo i smjelo. Mnoga kazivanja, poput navedenoga, govore o zabrani proslave blagdana Majke Božje Snježne, a odnose se na vrijeme neposredno iza Drugoga svjetskog rata. ${ }^{7}$ No, pored takvih kazivanja postoje i kazivanja koja ukazuju na to da je usprkos zabrani postojao kontinuitet vjerovanja, ali i obilježavanja blagdana Majke Božje Snježne, a odnose se na isto to vrijeme. ${ }^{8}$ Kazivanje Anke Prpić iz Matića potvrđuje postojanje svojevrsne slobode: ... niti je ko komu branija. Iako je bija komunizam

6 Nedorečenost razumijevanja vjerovanja u Majku Božju Snježnu mogla bi se objasniti još jednom činjenicom: kazivači su pričajući o Majci Božjoj Snježnoj mahom govorili i o Majci Božjoj Krasnarskoj, ali često ih svjesno odvajajući u dva lika, koja kontinuirano supostoje. Primjer za to je navod Ivana Krmpotića iz Šojatskoga Dolca prema kojem se ljudi zbog bolesti više zavjetuju Majci Božjoj Krasnarskoj, nego Majci Božjoj Snježnoj. Također, zabilježeno je i preklapanje tih dvaju likova i u svijesti kazivača, primjerice Milana Krmpotića iz Veljuna: A tobož da je tamo (misli na Krasno) taj veći zbor, blagdan i da je baš to točno tamo gdje je Majka Božja prvi puta osvanula, ta Snježna. A ovdje kasnije, tu na Krivom Putu.

Stjepan Prpić Stipina, Klarićevac; Ivan Tomljanović Blitva, Podbilo.

8 Eleonora Prpić, Veljun; Ivan Tomljanović, Podbilo. 
... Ko je ima želju, u crkvu je moga ić kad je god tija. Iako su dva navedena pogleda na to vrijeme na očigled oprečna, o njihovu supostojanju u istom vremenu svjedoči i sljedeće kazivanje: Onda se poslije rata, iza 1950. više počelo ić u crkvu. Baš kad se branilo. ${ }^{9}$ Unatoč tome što je ove godine kod kazivača prevladavao dojam da u proslavi blagdana neće biti toliko sudionika kao posljednjih nekoliko godina ${ }^{10}$, prema dvama kazivanjima broj ljudi koji dolaze proslaviti blagdan od devedesetih godina 20. stoljeća znatno se povećao ${ }^{11}$.

Istaknule bismo da je proslava blagdana mijenjana s promjenama političkih, ali i ekonomskih uvjeta. Marko Pavelić Mijatina iz Podbila kazuje: Onda poslije Drugog rata su se počeli zapošljavat po Senju, Rijeci... i tako iseljavat. Negdje od 1965., 1970. je počeo taj val iseljavanja, a to najviše zbog toga što nije bilo struje, uvedena je tek 1969. godine... Cesta je asfaltirana 1973. godine. Isti kazivač naveo je da je pilana, locirana par kilometara od Alana, zbog političkih razloga 1966. godine bila zatvorena, što je doprinijelo iseljavanju ${ }^{12}$. Još je jedno sjećanje Miroslave Filipaš iz Podbila na takve uvjete bez struje i vode. Kazivanje Ivana Tomljanovića Rokina iz Vrataruše potvrđuje utjecaj političkih i ekonomskih faktora na svakodnevni život ljudi tog kraja: Bio je sistem da je sve ljude trebalo selit odavde. Nisu davali struju, vodu, ništa. Iako bi se na prvi mah moglo razmišljati o negativnom utjecaju ekonomskih faktora i na posjećenost proslave blagdana, dugogodišnje iseljavanje rezultiralo je upravo suprotnim: iseljeni Krivopućani sa svojim obiteljima nastoje upravo taj dan biti u Podbilu. Blagdan Majke Božje Snježne postao je dan okupljanja krivoputske zajednice i prigoda za susret.

Struktura ovog priloga proizašla je iz okosnica formiranih u procesu istraživanja. Naime, u istraživanju vjerovanja u svece zaštitnike kao dijela pučke pobožnosti, kazivači su sami isticali Majku Božju Snježnu kao sveticu koju doživljavaju kao važan aspekt u oblikovanju identiteta lokalne zajednice. Brojnim kazivanjima grupirale su se i raznovrsne podteme, a mi ćemo ih u ovom prilogu prikazati određenim slijedom; krenule smo od predaja vezanih uz izgradnju crkve posvećene Majci Božjoj Snježnoj, o kojima su kazivači vrlo rado govorili. Predaja nam je u ovom radu važna iz dva razloga: jedan je uvrštavanje osobnog u predaju, kroz što možemo promatrati osobno vjerovanje u Majku Božju Snježnu ${ }^{13}$, a drugi je uloga koju ona ima u oblikovanju lokalnog identiteta. Idući odlomak odnosi se na molitve i zavjete upućene Majci Božjoj Snježnoj gdje ćemo nastojati ukazati na promjene značenja termina zavjet s kojima smo se susrele. Naime, govoreći o zavjetu, neki kazivači imali su na umu događaj ispunjen druženjem i zabavom, a ne svojevrsnu komunikaciju između čovjeka i svetog. Nadalje, procesija je važan dio obilježavanja blagdana. Upravo spregom sudjelovanja na proslavi blagdana Majke Božje Snježne 5. kolovoza 2004. godine te kazivanja dobivenih u svibnju 2004. godine, možemo izdvojiti opise proslave blagdana te ih komparirati s podacima dobivenim vlastitim sudjelovanjem. Završni dio ovog priloga bit će detaljan etnografski opis proslave blagdana 2004. godine.

\section{MAJKA BOŽJA SNJEŽNA U OBLIKOVANJU IDENTITETA ZAJEDNICE}

I skazi o Majci Božjoj Snježnoj u Krivome Putu veoma su važni stoga što ukazuju koliko i kako je Majka Božja Snježna pojavom i značenjem integrirana u lokalnu zajednicu. Majku Božju Snježnu kazivači doživljavaju i opisuju uvijek u odnosu spram drugih svetaca. Kao što smo istaknule u uvodu, to je uočeno i tijekom prvog istraživanja kada su se kazivanja o svecima zaštitnicima mahom usmjeravala na Majku

Jedini podatak o kazivaču je godina njegova rođenja (1940.). Razgovor je obavljen 5. kolovoza 2004. godine u gostionici u Podbilu.

10 Marija Tomljanović Čnina, Podbilo; Mara Tomljanović Isanova, Krivi Put; Marko Pavelić Mijatina, Podbilo.

11 Stjepan Prpić Stipina, Klarićevac; Ivan Tomljanović Blitva, Podbilo.

12 Više o iseljavanju vidi u prilogu M. Rajković u prvom svesku Monografije, str. 79-94.

13 Budući da su u ovom radu uglavnom prikazana kazivanja i postupci koji ulaze u domenu privatnog i osobnog, iz etičkih razloga nisu uvijek navedena imena kazivača. 
Božju Snježnu. Vjerovanje u Majku Božju Snježnu na taj se način može shvatiti ne samo kao dio osobnog identiteta, već i identiteta zajednice. Tako je Jure Tomljanović iz Podbila na pitanje o sv. Jurju, svecu koji je također prisutan u vjerovanjima Krivopućana, odlučno odgovorio: Sveti Juraj je zaštitnik grada Senja, a nije Krivog Puta! Naš je zaštitnik Majka Božja Snježna, dajući do znanja da bismo u prome redu trebali o njoj razgovarati.

Prema kazivanju Vlade Filipovića iz Krivoga Puta, Majka Božja Snježna ima važnu ulogu i u povijesti zajednice krivoputskih Bunjevaca jer, kako je istaknuo, lik Majke Božje Snježne u svojim su vjerovanjima Bunjevci nosili još u seobi kao svoju zaštitnicu i donijeli je u Krivi Put.

Majka Božja Snježna spominje se u inačicama poput: zaštitnica našeg mjesta ${ }^{14}$, naša svetica ${ }^{15}$, naša zaštitnica ${ }^{16}$ ili pak kao lokalna zaśtitnica ${ }^{17}$

\section{PREDAJE O IZGRADNJI CRKVE MAJCI BOŽJOJ SNJEŽNOJ}

$\mathrm{P}$ rema kazivanjima, Majka Božja zadobila je atribut Snježna zbog široko rasprostranjene predaje o tome kako je 5. kolovoza pao snijeg u trenutku kada se ukazala pa je na mjestu ukazanja podignuta i crkva. ${ }^{18}$

Malo složeniju varijantu predaje čine kazivanja o utjecaju Majke Božje Snježne na promjenu mjesta izgradnje crkve. Naime, prema toj predaji crkvu su namjeravali i počeli graditi na nižem mjestu, kod zdenca (šterne), ali se njezin lik na snijegu pojavljivao (jednom, dvaput ili neodređen broj puta) na drugom mjestu, gdje je naposljetku izgrađena današnja crkva. ${ }^{19}$ U ovoj varijanti Kata Pavelić iz Pavića navodi da se Majka Božja Snježna na snijegu neprestano prikazivala u obliku ljiljana, dok Stjepan Prpić iz Klarićevca govori o ruži uz koju se pojavio lik Majke Božje Snježne ${ }^{20}$. Zanimljivo je kako se prema istom kazivaču promjena mjesta izgradnje crkve odrazila i na izgledu kipa Majke Božje Snježne: I onda su napravili crkvu (...) ne tu di je trebalo, pa ona zato drži glavu na koso, pa se zove i Majka Božja Žalosna.

Među razloge podizanja crkve u čast Majke Božje Snježne može se pridodati i već spomenuta predaja o nošenju lika Majke Božje Snježne kao svoje zaštitnice kroz seobu i o njezinu donošenju u Krivi Put iz Like, vjerovanje koje nam je ispričao Vlade Filipović iz Krivoga Puta.

Samo je Gojko Tomljanović iz Podbila spomenuo predaju vezanu uz turske pohode na tim područjima: Jedni govore da su, kad su s Turcima ratovali tu, da je snijeg pao, da su se Turci povukli pa je podignuta crkva njoj u čast.

Kazivačica Marija Tomljanović iz Podbila navodi kako je 5. kolovoza, na blagdan Majke Božje Snježne, jedne godine prije Domovinskog rata padala susnježnica.

Čini se kako osnovna predaja o izgradnji crkve u Podbilu donekle odgovara onoj o nastanku crkve Santa Maria Maggiore u Rimu, s time što lokacije iskazane u domaćoj predaji odgovaraju području Podbila.

\section{MOLITVE I ZAVJETI}

$\mathrm{R}^{2}$ azlozi obraćanja Majci Božjoj Snježnoj u molitvama raznoliki su. Neki kazivači navode da se Majci Božjoj ljudi obraćaju za zdravlje (pet kazivača), zbog muškaraca (jedna kazivačica), za blago (jedan

\footnotetext{
Mara Tomljanović Isanova, Krivi Put.

Ana Šojat Švabina i Ante Šojat Tine, Šojatski Dolac.

Jure Tomljanović Ban, Podbilo.

Milan Prpić i Milka Prpić Markini, Veljun.

18 Ivan Krmpotić Šoparin, Šojatski Dolac; Joso Krmpotić, Veljun; Eleonora Prpić, Veljun ; Ivan Prpić Kavarica i Marija Prpić Kavarica, Lucići; Antun Špalj Franateov, Podbilo.

19 Marijo Taboga Balun, Šojatski Dolac; Ana Šojat Švabina i Ante Šojat Tine, Šojatski Dolac.

20 Gojko Tomljanović iz Podbila također govori o pojavi ružice u snijegu, ali ne u kontekstu promjene mjesta izgradnje crkve.
} 
kazivač), za lakši porod (jedan kazivač) i za sretan povratak sinova iz vojske tijekom Drugoga svjetskog rata (jedna kazivačica). Dvije kazivačice shvaćaju Majku Božju Snježnu kao univerzalnu zaštitnicu, a samo jedno kazivanje upućuje na to da se Majci Božjoj Snježnoj obraćalo za oproštenje grijeha. Prema nekim autorima, te molitve, osim posljednje koja spada u grupu molitvi za spas, svrstavaju se u instrumentalne molitve. Njima se traži Božja intervencija u vezi s problemom na ovome svijetu (bolest, ljubavni i obiteljski problemi i sl.). Vjernik se pritom može, ali ne mora, u slučaju pozitivnog ishoda, obvezati na neki čin. Obveze preuzete zavjetom variraju: plaćanje mise, darivanje svijećama i cvijećem, moljenje krunice, odlazak na hodočašće (katkad pješice i bosonog), rezanje kose, nošenje osobita odijela, obilaženje oltara ili crkve (katkad na koljenima), darivanje slike, votiva u obliku dijelova tijela, osobnih predmeta i dr. (Christian 1989:118-120).

Prilikom ovog istraživanja zabilježeno je mnogo podataka o zavjetovanju Majci Božjoj Snježnoj. Prema kazivanjima, na području Krivoga Puta žene su se više zavjetovale nego muškarci. Značajno je napomenuti kako je ovim istraživanjem broj obuhvaćenih muških i ženskih kazivača bio podjednak, tako nam slika dobivena temeljem kazivanja može služiti kao pokazatelj rodno definiranih razlika. Jedno tumačenje zašto su se žene više zavjetovale od muškaraca dao je kazivač iz Mrzloga Dola: Čemu bi se ja zavjetovao? To su žene prije išle na zavjet (...) One koje su grešne. Žene su uvijek više grešnije nego muški... ${ }^{21}$

Tijekom proslave blagdana 2004. godine kojoj smo i same prisustvovale, uočile smo neke radnje koje bismo mogle opisati kao zavjetne: prije i poslije jutarnje mise ljudi obilaze oltar uglavnom tri puta, pritom dotičući kutove oltara (sl. 2a, 2b ).
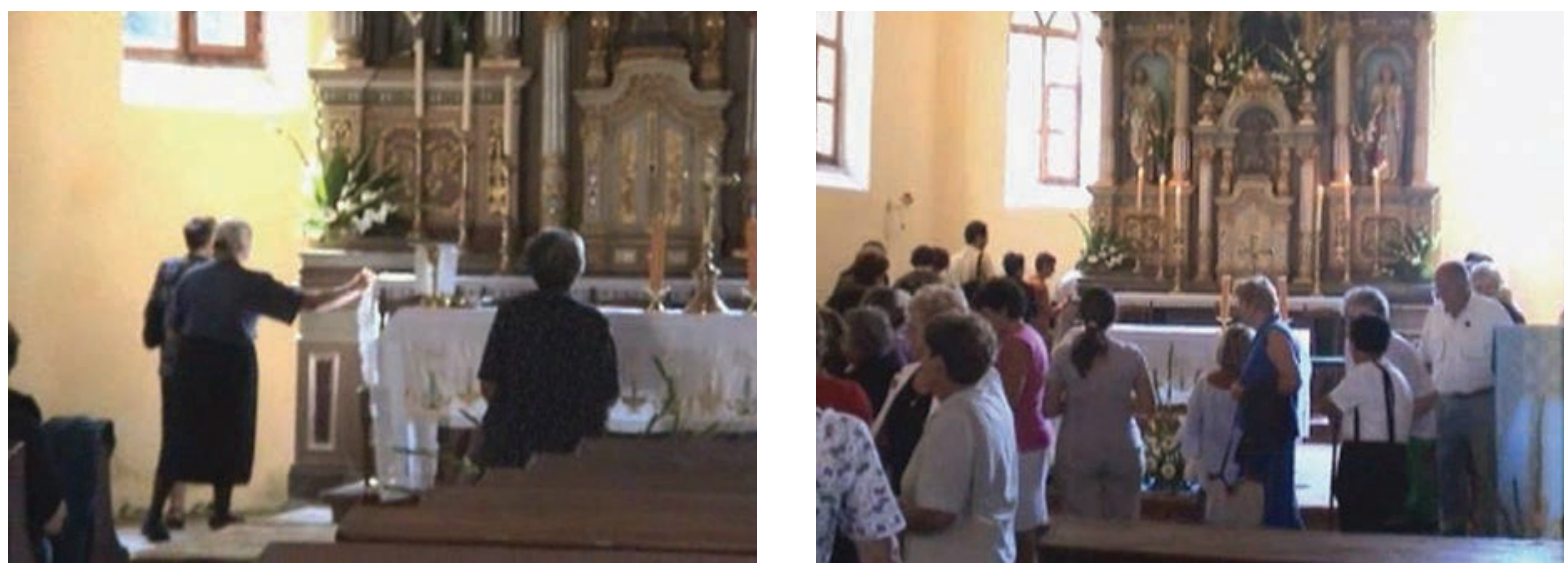

Slike 2a, 2b: Zavjetni obilasci okeo oltara Majke Božje Snježne, Podbilo; snimila Ivana Vukovic 5. kolovoza 2004.

Samo je nekoliko starijih žena obišlo oltar četiri puta. Nekoliko žena je pri obilasku oltara u rukama držalo krunice. Nakon obilaska zastali su pomoliti se pred oltarom, a neki potom i pred kipom Majke Božje Snježne. U većini slučajeva vjernici su doticali kip. Na poleđini oltara pronašle smo ispisane razne molitve i poruke upućene Majci Božjoj Snježnoj. Na koru su stajale dvije male uokvirene sličice Gospe - Majke Božje Bistričke i Majke Božje sa Svetih Gora (Slovenija). Moguće je da se radi o zavjetnim darovima.

Prema kazivanjima može se zaključiti da su se prije ${ }^{22}$ ljudi zavjetovali učestalije nego danas. Valja napomenuti kako se uspostavilo (iako smo prilikom razgovora i mi i kazivači koristili termin zavjet) da se značenje tog pojma nije uvijek podudaralo. Prema mnogim kazivačima, zavjet je ispunjavanje preuzete obveze prema svecu prigodom hodočašća, a hodočašća su isključivo zavjetna. Suprotno tome, neki kaziva-

21 Često u ovome poglavlju iz etičkih razloga nećemo navoditi imena kazivača.

22 S obzirom na godišta kazivača, prošlost o kojoj se govori možemo grubo datirati u vrijeme neposredno nakon Drugoga svjetskog rata. 
či koriste pojam zavjet za označavanje događaja ispunjenog zabavom i druženjem. ${ }^{23} \mathrm{U}$ takvom poimanju zavjeta, bez obzira što se odnosi na Majku Božju Krasnarsku, govori Ivan Krmpotić iz Šojatskoga Dolca: Cijelu noć je zabava. I tamo [priča o Krasnom] kad smo došli uvečer, onda mladi naročito nisu išli spavat... Ložili su vatre, tu se malo i ljubili. A obavezno ono kolo se igralo i pjevalo svakorazne pjesme. Razvidno je da pojam zavjet ljudi vezuju uz hodočašće. Štoviše, zavjetom često i nazivaju hodočašća. Dok jedni u hodočašću vide prigodu za ispunjenje zavjeta, drugima je ono prigoda za zabavu i druženje. Budući da i jedni i drugi, kako je navedeno, hodočašće nazivaju zavjetom, možemo zaključiti da se značenje pojma zavjet mijenja sukladno poimanju hodočašća. No, kako ne bi nastala zbrka u izlaganju teme, pojam zavjet rabit ćemo prema ranije iznesenoj definiciji.

Prema kazivanjima, ljudi su se zavjetovali i za sebe i za bližnje, premda je, prema našem dojmu, učestalije zavjetovanje usmjereno na vlastiti boljitak. Dvije kazivačice nisu htjele pričati o svom zavjetu niti načinu kako ga obavljaju jer ga shvaćaju kao tajnu koju svatko ima za sebe, te koju ne treba odavati. Zavjet se obavljao na sam dan Majke Božje Snježne, kako tko želi, prije ili poslije mise.

Svi kazivači navode da su ljudi na blagdan Majke Božje Snježne u Krivi Put dolazili pješice (sl. 3), kao i to da su neki dolazili bosi (uglavnom žene).

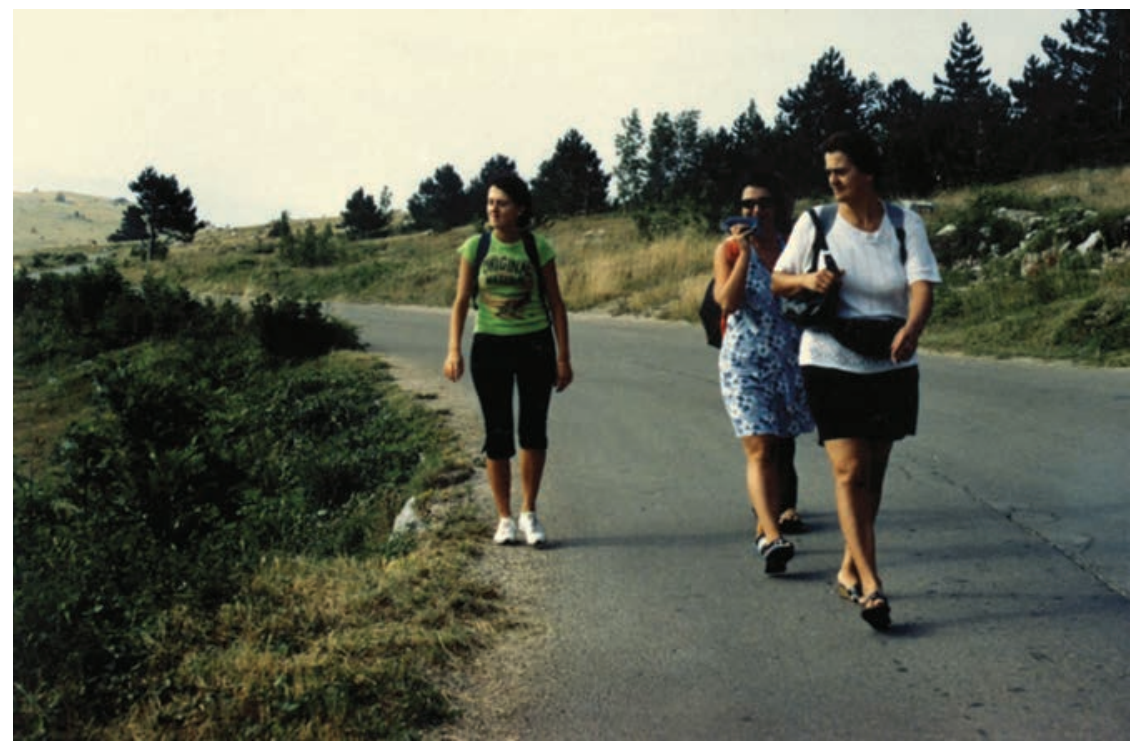

Slika 3: Dolazak vjernika pješice na spomendan Majke Bǒ̌zie Snježne; snimila Marija Kulišic 5. kolovoza 2004.

Dolazilo bi se do crkve, te obilazilo crkvu i oltar. Iz kazivanja je nejasno je li se uvijek obilazila i crkva i oltar ili samo jedno od toga. Oltar se obilazio tri puta, hodajući ili (češće) na koljenima, ovisno o tome kako se tko zavjetovao. Kazivačica Marija Tomljanović iz Podbila potvrdila je povezanost načina obavljanja zavjeta s uzrokom zavjetovanja, ali to nije znala detaljnije objasniti. Obzirom da to i ulazi u sferu osobnog, bilo je teže doći do takvih podataka, a neko opće pravilo (obrazac) nismo uočile.

Dobile smo dvije potvrde o dvostrukim, međusobno nepovezanim zavjetima: Majci Božjoj Snježnoj i Majci Božjoj Krasnarskoj. Kazivač iz Šojatskoga Dolca navodi kako im se objema zavjetovao, naglašavajući pritom da se za bolest zavjetovao Majci Božjoj Krasnarskoj. To kazivanje jasno ukazuje na već spomenuto poimanje o različitoj moći tih dvaju likova, tj. o kazivačevu razdvajanju Majke Božje u dva lika - Snježnu i Krasnarsku.

Na pitanje o zahvali Majci Božjoj Snježnoj za pruženu pomoć, kazivači su mahom odgovarali o novčanom obliku zahvale. U nekim se slučajevima uobičajeni milodar poima kao zahvala. No, iz nekih

23 Ivan Krmpotić Šoparin, Šojatski Dolac; Milan Krmpotić Zekonja, Veljun. 
kazivanja nije jasno je li novčana zahvala dio zavjeta ili ne. Naime, zbog promjene značenja pojma zavjeta (poistovjećivanje zavjeta s hodočašćem koje je poprimilo izraženije društveno-zabavne karakteristike) još je teže sa sigurnošću tvrditi radi li se o zahvalama koje su dio zavjeta ili ne.

Uz novac kao uobičajen oblik zahvale, bilo je i drugih zahvala. Marija Tomljanović Čonina iz Podbila svjedoči da bi žene poklonile kopertu, milje ili nešto za prekriti oltar, ili bi poklonile kakav tepih, ako bi imale viška. Pored navedenog, kako smo i uočile tijekom proslave blagdana, u znak zahvale Majci Božjoj Snježnoj pale se svijeće, daruje se cvijeće, plaća se misa, a prema kazivanju svećenika u pletenu košaricu koja se nalazi na oltaru ostavljaju se pisane poruke, pa čak i vrijedni osobni darovi (uglavnom nakit, prstenje). Jedna kazivačica iz Podbila naglašava da je bitno jednom u svetištu zahvaliti Majci Božjoj Snježnoj za ispunjen zavjet, dok narednih godina zahvala nije obvezna, ali je poželjna. Ista se kazivačica svaku večer prije spavanja zahvali Majci Božjoj Snježnoj.

I samo hodočašće u svetište može biti zahvala za ispunjenu molbu, kao što nam je to navela mlada djevojka koja je pješice došla iz Senja do crkve Majci Božjoj Snježnoj 2004. godine.

Votivi kazivačima nisu poznati, a i svećenik za područje Krivoga Puta Mile Čančar navodi da se s votivima u svom radu na tom području nije susretao.

U procesiji oko crkve, 5. kolovoza 2004. godine, uočile smo kako su neke žene rukom dodirivale lijevi stražnji, apsidalni dio crkve. U procesiji smo u kraćem razgovoru sa starijom ženom iz Podbila dobile jednu interpretaciju tog čina: ugao se dodiruje kako bi se učvrstila molitva upućena Majci Božjoj Snježnoj. Moguće da je i taj čin dio zavjeta.

\section{PROCESIJA}

$\mathrm{K}$ azivanja govore da je itinerer procesije na dan Majke Božje Snježne u Krivom Putu tijekom godina mijenjan. Kazivači se sjećaju kako je procesija kretala iz crkve do nedaleke kapelice sv. Ane te natrag u crkvu. ${ }^{24}$ Svećenik Mile Čančar navodi da je kapelica sv. Ane bila jedna od bitnih točaka u hodu procesije još početkom devedesetih godina 20. stoljeća, otkad je on počeo služiti misu u Podbilu. Glavni razlog zbog kojeg je skratio ophod samo na obilazak crkve bio je neprikladan spoj procesije i svjetovne varijante proslave tog dana. Naime, procesija je prolazila pored štandova i stolova za kojima su ljudi sjedili, jeli i pili, što je, prema mišljenju svećenika, narušavalo svečanost toga čina.

Ovogodišnja je procesija stoga obilazila samo crkvu (sl. 4a, 4b).

Prema kazivanju Anke Šolić Tutanove iz Podbila u procesiji su četiri mlađa čovjeka ${ }^{25}$ nosila kip Majke Božje Snježne iz crkve do kapelice sv. Ane gdje su ga spustili i stali zbog molitve. Zatim se procesija vraćala, obišla crkvu, te je nakon ulaska u crkvu počela misa. Sjeća se kako se u procesiji molilo i pjevalo Majci Božjoj, no ne sjeća se riječi pjesama. Ona spominje i to da su ljudi, nakon što je procesija ušla u crkvu i kip položen pored oltara, odlazili kleknuti pred kip. Miroslava Filipaš Cotina iz Podbila navodi podatak o tome da se jedno vrijeme u procesiji nosila slika Majke Božje Snježne, a ne njezin kip jer ga nije bilo, no kazivačica nije navela razlog nepostojanja kipa. Etnolog V. Belaj objašnjava kako čudotvorna moć nije neraskidivo povezana uz konkretan kip ili sliku, pa se na pojedinim mjestima može vidjeti da se štuju kopije starih, propalih kipova ili slika, pa čak i da se, na primjer, kip zamijenio slikom, a da se nije naudilo čudotvornoj snazi koju pok namjerava prizvati upomoć (Belaj, V. 1991:160).

Kazivačica Miroslava Filipaš iz Podbila ${ }^{26}$ navodi i to da je procesija, dok je išla do Sv. Ane, bila veselija te da je bila popraćena molitvom na glas i pjevanjem, za razliku od onih u zadnjih desetak godina. Procesiju 2004. godine doživljava kao jednu u nizu, kako ih ona naziva, utišanih procesija. Iako su ljudi 2004. godine u procesiji i pjevali, mogli bismo prema tom kazivanju zaključiti da se ranije pjevalo više.

24 Anka Šolić Tutanova, Podbilo; Jure Tomljanović Ban, Podbilo; Kata Pavelić Burgijina, Pavići.

25 Valja naglasiti da pojam mladeg čovjeka u ovom kontekstu označava subjektivno poimanje vremena kazivačice Anke Šlić Tutanove, posebno stoga što je kazivačica rođena 1932. godine.

$26 \mathrm{~S}$ tom smo kazivačicom i sudjelovale 2004 . godine u procesiji. 
Varijantu koja upućuje na mogućnost drukčijeg puta procesije iznio je Joso Krmpotić iz Veljuna. Procesija je išla oko crkve i u groblje dolje. A to je sve nekako blizu. Onda je bila jedna kapelica isto iza crkve, Sv. Ana se zvala, pa se išlo i to.
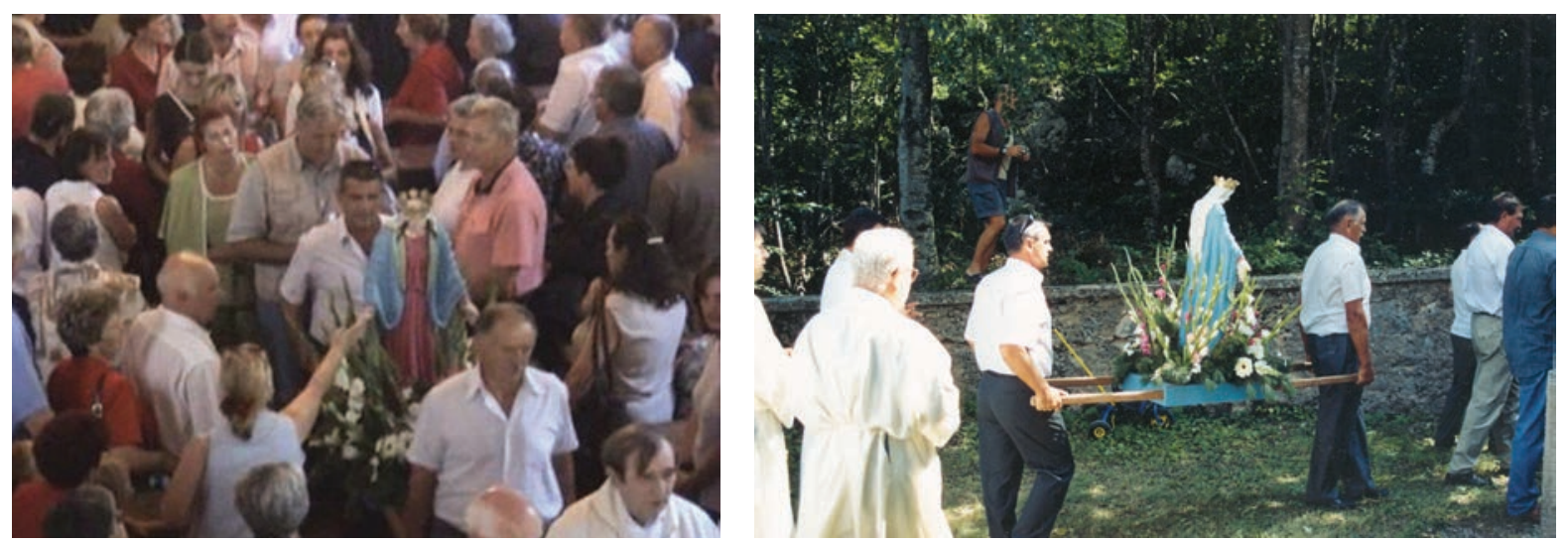

Slika 4a, 4b: Procesija s kipom Majke Bơ̌je Snje:̌ne na blagdan Majke Bơ̌̆je Snježne; snimila Marija Kuliší 5. kolovoz̧a 2004.

Nije naodmet spomenuti i procesiju koja se odvijala na Tijelovo ${ }^{27}$ i za koju su ljudi na različitim mjestima na otvorenom izrađivali tri $^{28}$ ili četiri oltara ${ }^{29}$, koji su se u procesiji obilazili. Prema kazivanjima to su bila mjesta Krivi Put, Podbilo i Alan ${ }^{30}$. Poviše oltara nalazile su se slike različitih svetaca. Važnost te procesije za našu temu ističe kazivanje koje svjedoči kako je među slikama svetaca ponekad bila i slika Majke Božje Snježne. Djevojke koje ukrašavaju oltare cvijećem i svijećama natjecale su se čiji će oltar ljepše izgledati. Prema kazivanju Eleonore Prpić iz Veljuna postojao je ispred oltara i stolić na koji bi svećenik kleknuo kad bi procesija stigla do toga mjesta.

\section{OBILJEŽAVANJE BLAGDANA MAJKE BOŽJE SNJEŽNE}

$\mathrm{P}$

roslava blagdana Majke Božje Snježne iskače iz svakodnevnice po svom vjerskom i društveno-zabavnom karakteru (sl. 5).

Događaj je integriran u svijest svih stanovnika Krivoga Puta kao jedina priliku da se sastanu ljudi, da se vide ${ }^{31}$. Spomenutu proslavu blagdana promatrale smo kroz njezina dva aspekta: sveti i svjetovni. U vezi s tim, želimo spomenuti i naše poimanje hodočašća, neizostavnog dijela proslave ovoga blagdana, koje se podudara s tumačenjima V. Belaja: Hodočašće je odlazak (hodanje; danas se ipak uglavnom odlazi prijevoznim sredstvima) na neko odredeno mjesto na kojem će hodočasnik moći ostvariti posebno prisan kontakt sa svetime (s božanstvom, s Bogom); od toga kontakta obično se zatim očekuje i nekakav koristan učinak (1991:159). V. Belaj u sastavne elemente hodočašćenja ubraja: motivaciju odlaska na hodočašće, sudionike hodočašća, put do mjesta hodočašćenja, cilj hodočašćenja i predmet koji se štuje (Ibid.). Uz to naglašava da bi se pozornost trebala usmjeriti na razne oblike pobožnosti, kao i na druge funkcije hodočašća koje među hodočasnicima dolaze do izražaja nakon obavljene pobožnosti, a to su: zabavna funkcija, razgledavanje, trgovanje i komunikacija (Ibid.:160-161). Model koji je autor predložio za istraživanje hodočašća u Hrvatskoj pokazao se relevantnim i pri istraživanju hodočašća Majci Božjoj Snježnoj. Uočile smo ambiva-

\footnotetext{
Mislimo da je važno upozoriti na podatak da se 2004. godine procesija na Tijelovo nije održavala.

Anka Šolić Tutanova, Podbilo; Kata Pavelić Burgijina, Pavići.

Milan Prpić i Milka Prpić Markini, Veljun.

Kazivanje o oltarima na četiri mjesta uključuje: Alan, Krivi Put, Veljun i Francikovac.

31 Anka Prpić, Matići.
} 


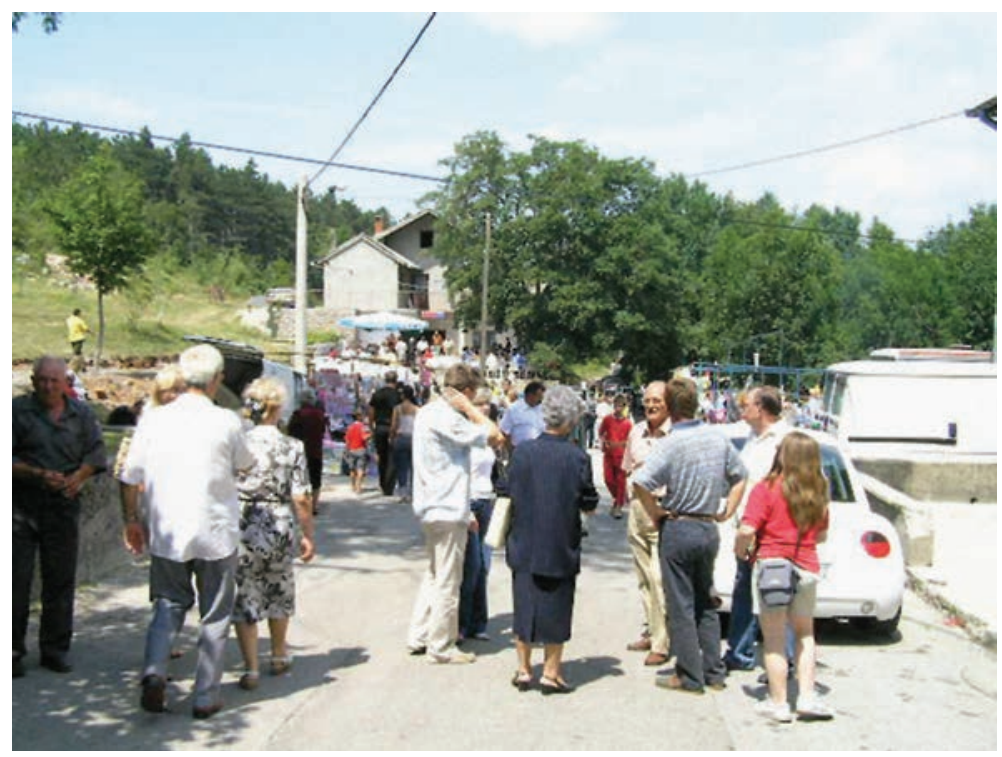

Slika 5: Centar Podbila i gostionica Luka, snimila Marijeta Rajkovic, 5. kolovoza 2004.

lentnost značenja proslave Majke Božje Snježne 5. kolovoza 2004. godine: većini Krivopućana važnost je bila sadržana u zabavnom aspektu proslave, pa bismo dan Majke Božje Snježne s tog stajališta mogli promatrati kao proštenje. S druge pak strane, ljudima koji su (iz bližih i udaljenijih mjesta) dolazili Majci Božjoj Snježnoj, taj dan bio je hodočašće.

Dva dana prije blagdana krenulo se s pripremama za svečanost u Podbilu. ${ }^{32}$ Nekoliko žena (uglavnom svake godine iste) očistile su crkvu te cvijećem okitile oltar i kip Majke Božje Snježne. (sl. 6a, 6b).
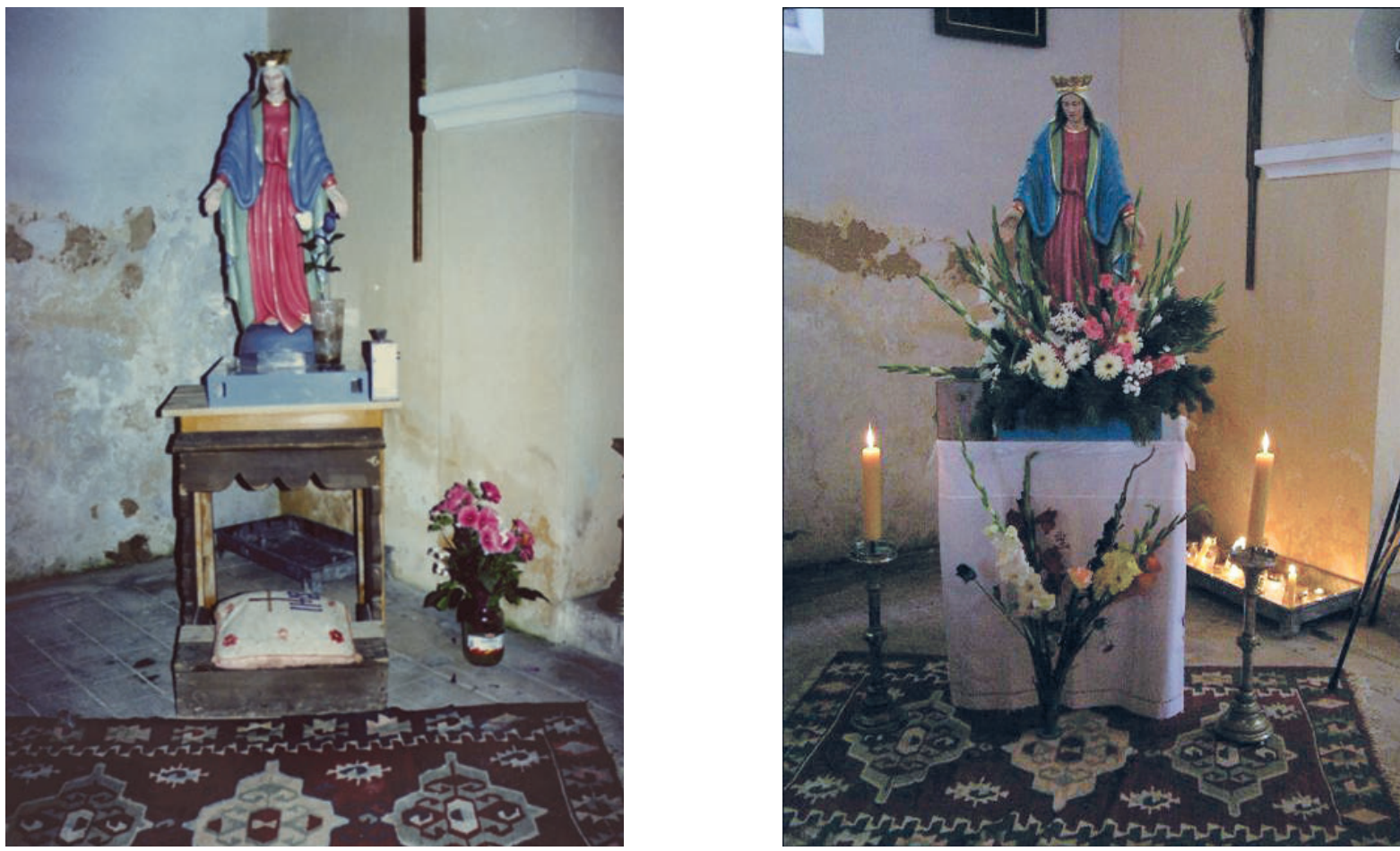

Slika 6a, 6b: Kip Majke Božje Snježne prije i nakon uređenja, 5. kolovoza 2004.; snimile Marija Kulisic i Marijeta Rajković.

32 Još jednom bismo istaknule da se podaci prikazani u ovom podnaslovu odnose na vrijeme iza Drugoga svjetskog rata, osim u slučajevima gdje je naglašeno da se podaci odnose na sadašnjost. 
Putem kazivanja doznalo se kako se na blagdan održavaju dvije do četiri mise, što vjerojatno ima veze s brojem hodočasnika, a broj održanih misa očito varira iz godine u godinu. Jutarnja misa u 8 sati 2004. godine nije bila održana, što može upućivati na manju popularnost svetišta. Dvoje kazivača iz Šojatskoga Dolca $^{33}$, te Anka Prpić iz Matića napominju kako je uobičajeni naziv za misu u 11 sati velika misa, dok se popodneva misa naziva blagoslov. ${ }^{34}$ Kazivačica iz Podbila misu u 16 sati doživljava kao zahvalu i blagoslov svećenika da se ljudima ostvari sve što su molili, dok se kazivačica iz Matića koja misu u 16 sati naziva blagoslovom, sjeća da je kao mlađa odlazila upravo na tu misu i nosila krunicu s ciljem da je blagoslovi. Pritom je spomenula da su drugi ljudi na blagoslov donosili i neke druge predmete, npr. manje slike (vjerojatno svetaca).

Na proslavu blagdana Majke Božje Snježne, prema kazivanjima, hodočasnici su dolazili iz različitih krajeva: Senja, Rijeke, Zagreba, Virovitice, Zagorja, Karlovca, Vinkovaca, Bjelovara, Slavonije te iz inozemstva: Njemačke i Australije. Dolazili bi osobnim automobilima i organiziranim prijevozom (autobusima (sl. 7).

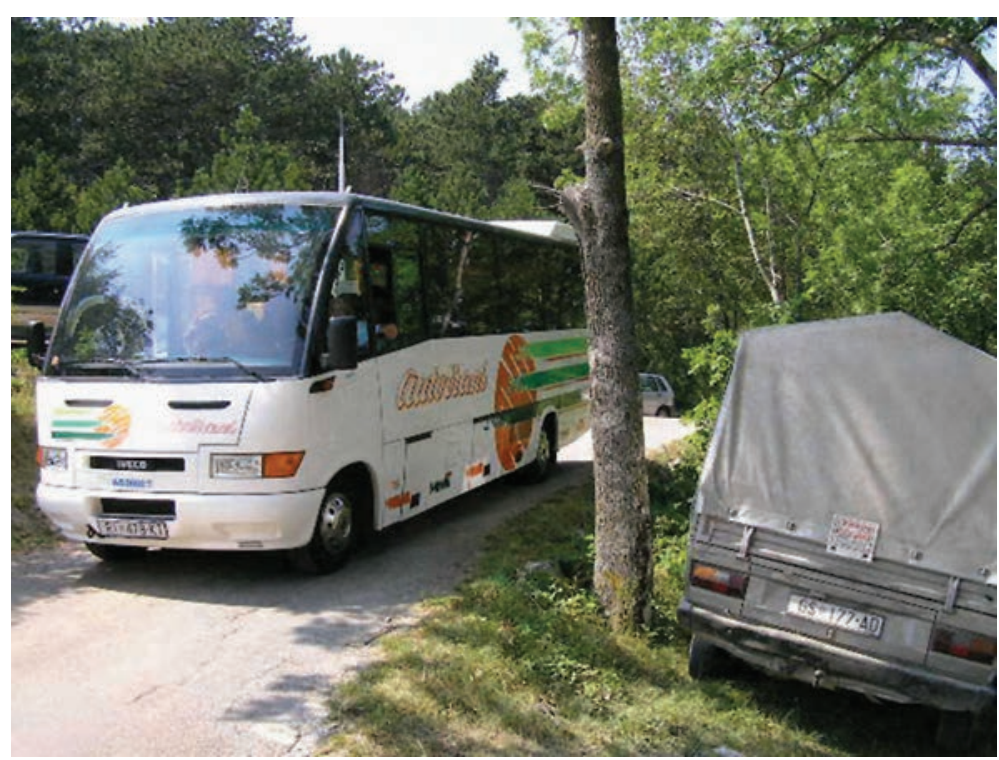

Slika 7: Organizirani dolaz̧ak na proslavu spomendana Majke Bơ̌zje Snježne, Podbilo; snimila Marijeta Rajković, 5. kolovoza 2004.

U odnosu na nekadašnja tri organizirana autobusa iz Senja ${ }^{35}$, 2004. godine u Podbilo je došao samo jedan. Milan Prpić Markin iz Veljuna sjeća se da se blagdan slavio tri do četiri dana, kao i dan poslije 5. kolovoza. Prema kazivanjima gotovo svih kazivača, a i prema uočenom, ljudi su ranije hodočastili pješice iz Senja. Antun Špalj Franetov iz Podbila navodi da bi zajedno dolazilo njih petnaestak do dvadeset, kako starijih, tako i mladih.

Iz kazivanja doznajemo da su žene odlazile natašte na ispovijed prije mise. Taj podatak bi se mogao odnositi na posljednjih pedeset godina. Prema kazivanju Marije Tomljanović Čonine iz Podbila u nekim je slučajevima ispovijed dio zavjeta, dok se za neke slučajeve to ne može tvrditi.

Sastavni dio proslave blagdana bila je procesija koja se odvijala na sam blagdan i to prije mise ${ }^{36}$.

33 Ana Šojat Švabina i Ante Šojat Tine, Šojatski Dolac.

34 Miroslava Filipaš Cotina, Podbilo i Anka Prpić, Matići.

35 Ivan Tomljanović Blitva, Podbilo.

36 Procesija je detaljnije prikazana u prethodnom odlomku. 
Lokalna gostionica žarište je zabavnih događanja. Ondje se peku janjci i uživo svira glazbeni sastav ${ }^{37}$. Zabava počinje u ranojutarnjim satima i traje do dugo u noć. Između crkve i gostionice, pored mjesta gdje se peku janjci, nalaze se štandovi s jelom, pićem, vjerskim i ostalim suvenirima, igračkama, ukrasima za kosu, torbicama, slamnatim šeširima, umjetnim cvijećem i dr. (sl. 8)

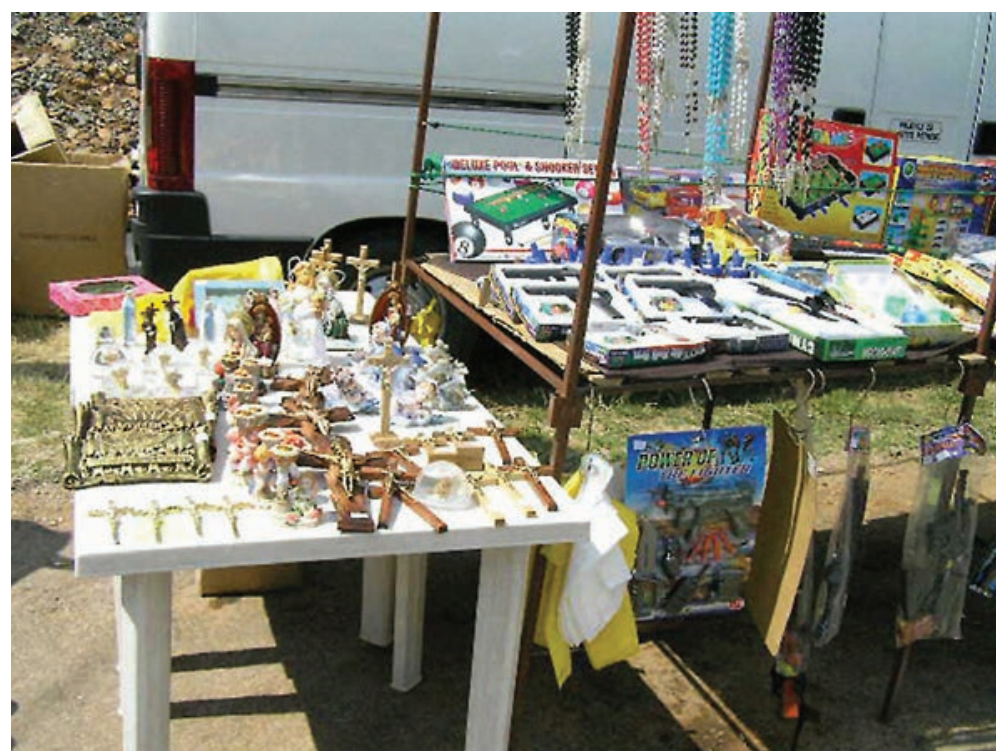

Slika 8: Štand s raznorodnim suvenirima, Podbilo; snimila Marija Kulisicí 5. kolovoza 2004.

Stariji kazivači sjećaju se plesanja kola na petunu ispred crkve, dok se generacije nakon Drugoga svjetskog rata tog kola sjećaju kao nečega što pripada iskustvu starijih: to su starije generacije, naše su već imale disko. ${ }^{38}$ Iako 2004. godine nije bio organiziran ples u obnovljenom Domu, više kazivača spomenulo je kako je i ples dio događanja.

Stariji su kazivači kroz razgovor pričali o hodočaśću na dan Majke Božje Snježne, dok su se mladi referirali uglavnom na zabavu. To pokazuje kako su hodoćašća složen fenomen kojem je nemoguće cjelovito pristupiti ukoliko se istražuje samo jedan njegov aspekt. Kao primjer složenosti tog fenomena navodimo kazivanje nekolicine mladića o razlogu svoga dolaska: A razlog je taj: tradicija, i Snježna Gospa, i turnir se održava nogometni. ${ }^{39}$ Tome u prilog idu još neka kazivanja koja u prvi plan stavljaju susret s ljudima i zabavu $^{40}$. Skupina mladih rođenih između 1982. i 1987. godine navode kako su ove godine ondje zbog roštiljade. ${ }^{41}$

Proslavu Majke Božje Snježne već devet godina prate nogometni turniri, koji su pak vezani i uz obilježavanje vojne akcije Oluja. Na tim turnirima prisutno je dvjesto do tristo ljudi. Igraju se prijateljske utakmice s klubovima iz raznih područja Hrvatske. Ove godine NK Bunjevac igrao je protiv Tigrova iz Ogulina i bunjevačkog nogometnog kluba iz Virovitice. ${ }^{42}$

\footnotetext{
37 Proslavu blagdana pratila je uvijek i „živa glazba“ koja ni 2004. godine nije izostala.

Miro Prpić Ropeta, Krivi Put; Josip Prpić Paljak.; Krivi Put.

39 Dvojica vatrogasaca u uniformi i jedan mladić u civilnom odijelu, koji su čuvali cisternu; rođeni 1971., 1980. i 1968. godine.

40 Primjerice kazivanje Stipe Prpića iz Klarićevca.

41 Nemamo podatke o ovim kazivačima.

42 Miro Prpić Ropeta, Josip Prpić Paljak Krivi Put, Marko Tomljanović Pešo (koji čine upravu Kluba).
} 


\section{BLAGDAN MAJKE BOŽJE SNJEŽNE 2004. GODINE}

U ovom će dijelu biti prikazana naša zapažanja stečena dan uoči proslave blagdana Majke Božje Snježne te na sam dan, 5. kolovoza 2004. godine. Podaci prikazani u ovom dijelu rezultat su drukčijeg pristupa istraživanju iste teme u odnosu na istraživanje provedeno u svibnju 2004. godine kada je glavna tehnika rada bila polustrukturirani intervju. Prisustvovanje proslavi blagdana Majke Božje Snježne u ulozi sudjelujućih promatrača omogućilo nam je dublje i cjelovitije razumijevanje našeg istraživanja vjerovanja u Majku Božju Snježnu kao dijela pučke pobožnosti.

Dan uoči proslave blagdana u Podbilu tekle su pripreme za slavlje. U lokalnoj gostionici u blizini crkve već tijekom jutra ljudi su razgovarali o sutrašnjem danu. Razgovori su se uglavnom odnosili na pripreme vezane uz hranu i piće koje je trebalo osigurati u dovoljnoj količini. Naši upiti bili su jedini poticaj da se priča o Majci Božjoj Snježnoj. Ipak, i ti su odgovori više bili usmjereni na društveni aspekt događaja. Naime, pričali su o tome koliko će se ljudi sutra okupiti i iznosili pretpostavke o razmjerima nadolazećeg slavlja. Vlasnik gostionice rekao nam je kako je za ovu godinu kupio manje janjaca i vina nego prijašnjih godina. To je bilo sukladno dojmu ostalih ljudi u gostionici da će ovogodišnjoj proslavi prisustvovati manje ljudi nego na proslavama prethodnih godina. Unatoč tome, u gostionici, na tom očito bitnom lokalnom sastajalištu u Podbilu, osjećalo se iščekivanje i posebnost sutrašnjega dana.

Na proširenju između gostionice i crkve već su bili postavljeni prvi štandovi. Odlučile smo pogledati unutrašnjost crkve posvećene Majci Božjoj Snježnoj. Osim što nas je zanimala unutrašnjost crkve, zanimalo nas je i kako je crkva dan prije blagdana ukrašena. Ispred crkve je samo plakat, pričvršćen o stablo pred ulazom, informirao o nadolazećem danu. Obavještavao je o proslavi blagdana Gospe Snježne te Dana domovinske zahvalnosti. Bilo je istaknuto kako će se svete mise održavati u 11 i 16.30 sati, te da procesiju i sv. misu u 11 sati predvodi velečasni Ante Cvitković, župnik u Ličkom Lešću i dekan otočki sa svećenicima dekanata i gostima. Uz to je stajala i obavijest kako autobus iz Senja polazi u 9 sati.

U crkvi je bilo dvoje mladih ljudi. Kitili su cvijećem oltar i kip Majke Božje Snježne. Po njihovu mišljenju, važnost dana Majke Božje Snježne susret je stalnih stanovnika i raseljenih Krivopućana, koji (kako ističu) ne dolaze u Krivi Put za Božić i Uskrs, već upravo na blagdan Majke Božje Snježne. I njihovo kazivanje potvrđuje jednu od bitnih uloga proslave blagdana u životu lokalne zajednice - godišnje okupljanje.

Pored kipa Majke Božje Snježne, koji se nalazi lijevo od glavnog oltara posvećenog istoj svetici, u crkvi se još nalazi i kip sv. Antuna koji je također bio ukrašen cvijećem. Kraj njega je na zidu stajao uokviren natpis koji svjedoči da je kip poklon-zahvalnica gospođe Ruže. Sam kip smješten je lijevo od ulaza u crkvu Majke Božje Snježne, kraj škropionice. Nasuprot kipu, desno od glavnog ulaza, na zidu je slika sv. Tereze, u čijem je lijevom donjem uglu zapis o slici kao zavjetnom daru.

Izašle smo iz crkve i prošetale kroz mjesto nadajući se da ćemo naići na još neke pripreme. Sve je upućivalo na to da će se ljudi skupljati uglavnom oko crkve i gostionice.

Na sam dan, 5. kolovoza 2004. godine, krenule smo oko 8 sati u obilazak mjesta. Gostionica je već bila otvorena i nekoliko ljudi je ispijalo jutarnju kavu. Vlasnici štandova postavljali su suvenire za prodaju. Željele smo istovremeno prisustvovati raznim događanjima (u crkvi, u gostionici i na ulici), tako da smo se u istraživanju razdvojile.

U tim jutarnjim satima tekle su pripreme za misu u 11 sati. Pred crkvom je bio stol na kojem su se za prodaju nalazili: svijeće, drvene krunice, križevi, molitvenici i Biblije.

Dvoje mladih, s kojima smo jučer razgovarale u crkvi, palili su svijeće na oltaru i dvije velike svijeće pred kipom Majke Božje Snježne. Na taj su kip tijekom cijelog dana ljudi palili manje svijeće i stavljali ih pored ili iza kipa. Mladić je na desni kut glavnog oltara stavio košaricu za (kako je sam dan ranije naveo) novce i poruke. Na prvoj klupi slijeva, pred kipom, nalazila se još jedna drvena kutijica u koju su ljudi ubacivali novac.

Ljudi su u crkvu dolazili sami ili u društvu, pomolili bi se ili samo razgledati crkvu. Nekoliko žena starije dobi sjedilo je na klupama i molilo krunicu. Neke su molile pred kipom Majke Božje Snježne, neke 
pred oltarom, a neke pred kipom sv. Antuna. Cijelo jutro (do početka mise) trajala je ispovijed. Nekoliko starijih žena, među njima i jedan muškarac, obilazili su oltar tri puta s lijeva na desno. Uglavnom su oltar obilazili neovisno jedan o drugome, mada je bilo slučajeva obilaska u paru. Veoma je zanimljivo da je svega nekoliko žena oltar obišlo četiri puta. Neki bi se u tom hodu prekrižili, no svi su doticali oltar i to uglavnom kako njegov lijevi, tako i desni ugao. Dotičući oltar, neke su žene dlanom izvodile znak križa. Nitko nije obilazio oltar na koljenima, niti bos. Zapazile smo da je jedna od žena tijekom obilaska cijelo vrijeme u ruci nosila svijeću. U zadnjem je krugu ubacila nešto u košaricu postavljenu na oltaru, zatim zastala nešto duže pred oltarom te potom zapalila svijeću pred kipom Majke Božje Snježne. Dvije su pak žene u rukama nosile krunicu. Nakon što su obišle oltar tri puta, više je žena zastalo pomoliti se pred kipom Majke Božje Snježne. Pritom su ga dodirivale, a jedna je starija žena prvo ljubila ruku, pa istom rukom doticala kip. Zatim su uglavnom zastajale još i pred kipom sv. Antuna, križajući se i također ga dodirujući. Te koje su zastajale i pred kipom sv. Antuna, pred crkvom su kupile svijeću koju su odmah potom, vraćajući se u crkvu, palile pred njegovim kipom. Jedna starija gospođa koja je obišla oltar tri puta, dodirujući kutove oltara pri svakom obilasku, predložila nam je da i same to iz zavjeta učinimo. Nakon što smo joj rekle da ne znamo za što bismo se zavjetovale, odgovorila je kako nije ni važno, već da samo obiđemo oltar. Ovdje valja napomenuti da bismo pri interpretaciji vidljivih elemenata u vjerovanju trebali biti veoma oprezni jer je moguće da vjernik obavlja neke radnje (moli se ili obilazi oltar) iz duboke pobožnosti, a da to ne uključuje zavjet.

Za to vrijeme povećao se broj ljudi u crkvi - oko 9.30 sati stigao je autobus iz Senja.

U međuvremenu su se stolovi u gostionici popunili i počeli su peći janjce. U isto vrijeme iz Senja je dopješačila grupa ljudi. Njihov je dolazak pridonio zahuktavanju ozračja. Događaj smo pratile kroz dva žarišna mjesta zbivanja: jedno je bila crkva, a drugo gostionica (i prostor pred gostionicom).

Ljudi su se počeli okupljati oko crkve i u crkvi već oko 10.30 sati, iskoristivši to vrijeme prije početke mise za molitvu ili druženje. Okupili su se kako žene i muškarci svih generacija, tako i djeca. Jutarnja misa započela je procesijom. Nekoliko trenutaka prije procesije ozračje je bilo nabijeno emocijama, tako da je čak nekoliko ljudi, uključujući i jednu mladu majku s djetetom u naručju, bilo ganuto do suza. Kada je župnik preko oltara pozvao ljude da krenu u procesiju, mnogi su se progurali do središnjeg prolaza crkve s namjerom da dotaknu kip Majke Božje Snježne i to uglavnom za ruku. Taj trenutak formiranja procesije doživjele smo kao najsnažniji dio proslave blagdana, kao njezin vrhunac. Već tijekom mise slabila je emotivna nabijenost. Atmosfera nakon procesije i mise postajala je tijekom ostatka dana sve opuštenijom.

$\mathrm{Na}$ čelu procesije bila su četiri ministranta. Prvi od njih nosio je kandilo, drugi raspelo, dok su posljednja dvojica u rukama nosili svijeću. Iza njih, dva sredovječna muškarca nosila su kip Majke Božje Snježne. Za njima je slijedilo devet svećenika koji su prisustvovali crkvenom slavlju, te župni zbor. Ovogodišnja procesija išla je oko crkve. Iako je zbor s ponavljanjem pjevao pjesmu Majci Božjoj Snježnoj, nisu je prihvatili svi sudionici u procesiji, pa se pjesma među zadnjim sudionicima procesije nije ni čula. Neke su starije žene dodirivale lijevi vanjski dio crkvene apside. Jedna gospođa, u čijem smo društvu hodale u procesiji, savjetovala nam je da na tom mjestu dodirnemo crkvu, rekavši da ćemo tim činom učvrstiti molitvu koju za vrijeme procesije upućujemo Majci Božjoj Snježnoj.

Nakon ulaska u crkvu započela je misa koju je predvodio velečasni Ante Cvitković. Za vrijeme mise bilo je mnogo ljudi oko crkve, a gostionica je bila popunjena. Takav podatak i nije neobičan jer su hodočasnici mahom gostionicu šaljivo nazivali malom kapelom.

Nakon svršetka mise, mladi i stari, muškarci i žene, obilazili su oltar. Neki su dodirivali lijevi ugao oltara, neki su molili pred kipom Majke Božje Snježne. Dvije su žene klečale i molile ispred oltara. Iskoristile smo trenutak nakon mise i same obišle oltar. Na poleđini oltara pronašle smo ispisane molbe i zahvale vjernika upućene Majci Božjoj Snježnoj.

Odmah nakon mise u gostionici je počeo svirati tročlani sastav na trima instrumentima: harmonika, klavijature i berda. Jedina dulja stanka glazbenog sastava do ranih jutarnjih sati bila je u vrijeme popod- 
nevne mise u 16.30 sati, koju je predvodio velečasni Mile Čančar. Na toj misi bilo je znatno manje ljudi nego na onoj u 11 sati. Uglavnom su to bile žene, od kojih smo neke susrele i na jutarnjoj misi. Kako prije, tako ni poslije mise, nije bilo obilaska oltara i molitvi pred kipom. Svećenik je pred kraj mise blagoslovio sve prisutne.

Za vrijeme popodnevne mise trajao je nogometni turnir na obližnjem igralištu. Igrale su se dvije utakmice četiriju momčadi: NK “Bunjevac”, NK “Novi Vinodolski”, NK “Tigar” i NK "Nehaj”.

Cijelo je vrijeme trajala zabava u gostionici. Kad se smračilo, štandovi su se zatvorili, a gostionica je postala jedino mjesto na kojem se proslavljao blagdan Majke Božje Snježne.

Iako je povod zabave bilo štovanje lokalne zaštitnice Majke Božje Snježne, primijetile smo da među sudionicima proslave blagdana, kao i među hodočasnicima, nakon popodnevne mise o njoj nije bilo više spomena.

Iseljeni i stalni stanovnici Krivog Puta sa svojim obiteljima, kao i neki od hodočasnika, ostatak su dana proveli u gostionici, u opuštenom ozračju. Ljudima je bilo drago vidjeti iseljene sumještane, a mladi su to vrijeme koristili za upoznavanje. Kako je vrijeme odmicalo, ljudi su postajali sve opušteniji, djelomice i zbog popijenoga vina. Oko ponoći se znatno smanjila ponuda hrane i vina, no to nije pokvarilo dobro raspoloženje. Premda atmosfera u gostionici još nije najavljivala prestanak zabave te je bilo mnogo ljudi koji su plesali i pjevali, oko četiri sata ujutro, zbog iscrpljenosti, napustile smo proslavu ${ }^{43}$.

\section{ZAKLJUČNA RAZMATRANJA}

$\mathrm{M}$ olitve kojima se hodočasnici obraćaju Majci Božjoj Snježnoj najčešće su vezane uz rješavanje problema vezanih uz ovozemaljski život. Najčešće joj se Krivopućani mole radi ozdravljenja. Majci Božjoj Snježnoj zavjetuju se većinom žene. Ispunjenje zavjeta odvija se na blagdan Majke Božje Snježne, prije ili poslije glavne mise. Osoba koja se zavjetuje obilazi oltar crkve tri puta, slijeva nadesno, pritom uglavnom dodirujući i lijevi i desni ugao oltara. Nakon obilaska oltara odlazi se do kipa Majke Božje Snježne. Pred kipom se zastaje i moli. Novčani prilog uobičajen je oblik zahvale Majci Božjoj Snježnoj, no nedovoljno je istraženo radi li se o zavjetnoj zahvali. Za sam zavjet važno je spomenuti dodirivanje lijevoga vanjskog dijela crkvene apside tijekom procesije. Iako taj čin, koji su mahom vršile starije žene, ne možemo dovesti u izravnu vezu sa zavjetom, željele bismo ukazati na mogućnost da je i on dio zavjeta, što treba doznati daljnim istraživanjem.

Proslavu blagdana Majke Božje Snježne promotrile smo kroz dva važna aspekta: sveti i svjetovni. Pokušale smo odvojiti zbivanja vezana uz hodočašće, od onih zabavnog karaktera i to stoga što u proslavi sudjeluje lokalno stanovništvo koje se ne može smatrati hodočasnicima, a proslava s njihova stajališta primarno ima značenje proštenja. Hodočasnici pak dolaze iz različitih krajeva: Senja, Rijeke, Zagreba, Virovitice, Zagorja, Karlovca, Vinkovaca, Bjelovara, Slavonije te iz inozemstva: Njemačke i Australije.

Dvojak pristup istraživanju teme pokazao se pogodnim pri istraživanju proslave blagdana Majke Božje Snježne na području Krivog Puta jer je, kako smo ranije naglasile, pokazao dvostruki značaj proslave blagdana. Proslava blagdana Majke Božje Snježne za Krivopućane važna je kao hodočašće, ali i važno društveno i simboličko događanje na kojem se obnavljaju i jačaju rodbinske i prijateljske veze. Lik Majke Božje Snježne ima važnost pri oblikovanju identiteta pojedinca i lokalne zajednice.

43 Dodale bismo kako smo prigodom proslave blagdana Majke Božje Snježne 5. kolovoza 2004. godine susrele mnoge kazivače s kojima smo u svibnju iste godine prethodno bile razgovarale o samoj proslavi i pobožnosti prema Majci Božjoj Snježnoj. 


\section{LITERATURA:}

BELAJ, Vitomir (1991): Kulturološka obilježja hodočašćenja. Dometi, 24, 1/2/3, Rijeka, 157-162.

CHRISTIAN, A. William, Jr. (1989): Person and God in a Spanish Valley. Princeton, Princeton University Press.

HOŠKO, Fanjo Emanuel (2001): Franjevci i poslanje Crkve u kontinentalnoj Hrvatskoj. Zagreb, Kršćanska sadašnjost.

JUKIĆ, Jakov (1988): Povratak svetoga. Rasprava o pučkoj religiji. Split, Crkva u svijetu. 